This PDF is a selection from an out-of-print volume from the National Bureau of Economic Research

Volume Title: Tax Policy and the Economy: Volume 2

Volume Author/Editor: Lawrence H. Summers, editor

Volume Publisher: MIT Press

Volume ISBN: 0-262-19272-1

Volume URL: http://www.nber.org/books/summ88-2

Publication Date: 1988

Chapter Title: Taxation and U.S. Multinational Investment

Chapter Author: James R. Hines, Jr.

Chapter URL: http://www.nber.org/chapters/c10936

Chapter pages in book: (p. 33 - 62) 


\title{
TAXATION AND U.S. MULTINATIONAL INVESTMENT
}

\author{
James R. Hines, Jr.
}

Princeton University and NBER

In 1985, nonbank U.S. multinational companies employed 24.5 million workers, had worldwide sales of almost $\$ 3.5$ trillion, and net income of $\$ 150$ billion on assets of $\$ 4.2$ trillion. The foreign (non-U.S.) affiliates of these companies had 6.4 million employees, $\$ 900$ billion of those sales, and $\$ 43$ billion of net income, with assets of $\$ 838$ billion. United States multinationals accounted for roughly three-quarters of total American merchandise exports in 1985 and half of total imports, with approximately 40 percent of each category arising from transfers within U.S. multinationals between American parent firms and their own foreign affiliates. ${ }^{1}$ And 1985 is widely regarded as a sluggish year for U.S. multinationals.

By any measure, U.S. multinationals play an important role in the world economy. Yet multinational corporations operate in economic and legal environments that are often extremely complex and subject to abrupt changes. Volatility in exchange rates is one recent example of such changes; the U.S. Tax Reform Act of 1986 (TRA) is another. The recent U.S. tax change seems likely to have a considerable effect on the net earnings U.S. multinationals can expect to get abroad.

This paper was prepared for presentation at the NBER Tax Policy and the Economy Conference, Washington, D. C., November 1987. I am grateful to Mark Gersovitz, Gene Grossman, David Hartman, Joosung Jun, Scott Newlon, James Poterba, Harvey Rosen, Lawrence Summers, and especially Daniel Frisch for helpful comments and to David Andres and Joseph Marucci of Price Waterhouse-Princeton for data they provided.

${ }^{1}$ Data on U.S. multinationals in 1985 is reported in Brereton (1987). 
This chapter analyzes the impact of the U.S. tax system on overseas investments of U.S. multinationals. The TRA is just the most recent in a series of significant changes over the last twenty-five years in the U.S. tax law that applies to the foreign earnings of U.S. companies. The issue of U.S. tax incentives for overseas investments arises time and again in policy debates in the United States, as the goals of domestic employment and competitiveness in foreign markets compete with each other for legislative support. There is a widely held view that the U.S. tax system encourages American companies to invest excessively abroad, thereby depriving this country of capital, jobs, and productivity growth. However desirable it may be to encourage U.S. companies to invest their capital abroad, there appears to be little in the way of hard analysis of current and past incentives provided by the U.S. tax system. This chapter argues that the U.S. tax system has served to discourage foreign investment by U.S. multinationals more than is widely believed, but that the TRA has substantially reduced this negative incentive.

Section 1 examines some of the striking effects that foreign country tax systems have had on U.S. multinational activity. Section 2 describes the method by which the United States taxes the foreign income of its multinationals, and some of the theoretical implications of this system. Section 3 presents and analyzes recent data on U.S. and foreign tax collections from U.S. multinationals. Section 4 examines the financial behavior of U.S. multinationals and its tax consequences. Section 5 presents new estimates of effective tax rates on U.S. multinational investments in selected countries and considers recent investment behavior in the light of these estimates. Section 6 is the conclusion.

\section{TAX HAVENS AND MULTINATIONAL ACTIVITY}

Foreign countries are free to choose whatever tax regimes they want to impose on multinationals operating within their boundaries. Not surprisingly, tax rates vary widely from one country to another. In addition, many countries have signed bilateral tax treaties with other countries providing for mutual special tax treatment of the income from each others' multinational investments.

Tax havens are countries with very low rates of taxation of foreign investment. The governments of these countries are presumably willing to sacrifice some potential tax revenue in return for the employment, technology, and capital that foreign multinationals can provide. For U.S. firms investing overseas, the most important tax havens include the Bahamas, the Netherlands Antilles, Bermuda, Panama, Hong Kong, Liberia, Luxembourg, and Switzerland. By offering very low tax rates to induce foreign 
TABLE 1

Tax Havens and U.S. Multinationals, 1982

\begin{tabular}{|c|c|c|c|c|c|}
\hline Country & $\begin{array}{l}\text { Foreign } \\
\text { source } \\
\text { taxable } \\
\text { income }\end{array}$ & GNP & $\begin{array}{c}\text { MNC } \\
\text { income } \\
\% \text { of } \\
\text { GNP }\end{array}$ & $\begin{array}{l}\text { Current } \\
\text { year } \\
\text { foreign } \\
\text { taxes }\end{array}$ & $\begin{array}{c}\text { Average } \\
\text { tax rate } \\
(\%)\end{array}$ \\
\hline Bahamas & $\$ 2,222$ & $\$ 840$ & 264.5 & 40 & 1.8 \\
\hline Netherlands Antilles & 1,152 & 1,370 & 84.1 & 196 & 17.0 \\
\hline Bermuda & 552 & 790 & 69.9 & 3 & 0.5 \\
\hline Panama & 1,259 & 4,060 & 31.0 & 239 & 19.0 \\
\hline All countries & 57,059 & - & 0.8 & 21,998 & 38.6 \\
\hline
\end{tabular}

Note: Dollar amounts are millions of current (1982) dollars.

Source: U.S. Department of the Treasury (1985).

investment, these countries provide a simple illustration of the ability of taxes to affect economic behavior.

Table 1 reports the taxable activity of U.S. multinationals in tax havens in 1982. A quick glance at the level of U.S. multinational earnings in the Bahamas, the Netherlands Antilles, Bermuda, and Panama is enough to suggest the conclusion that something, most likely favorable tax treatment, is inducing U.S. multinationals to concentrate an inordinate share of their income production in tax havens. ${ }^{2}$ And since (as will be discussed shortly) the tax law discourages U.S. multinationals with operations in low-tax countries from taking actions that make their foreign source income taxable, the true foreign source income generated in these tax havens is quite likely to be greater than the reported figures.

The common wisdom in government and industry circles is that U.S. multinationals have over the last twenty years become increasingly adept at planning their overseas investment and financing activity in order to minimize tax obligations. All other things equal, one obvious way to avoid taxes is to locate as much foreign income production as possible in tax havens. Of course, there may be more geographical discretion in some industries than in others. Table 2 explores recent trends in tax haven activity of U.S. multinationals. The tax haven fraction of worldwide pretax earnings of the controlled foreign corporations of U.S. multinationals rose from 11 to 20 percent over the period 1968-1982. As the table suggests, this use rise is largely attributable to a greater fraction of U.S. multinational profits coming from the wholesale trade and finance, insurance, and real

2 Strictly speaking, U.S. multinationals report inordinate earnings in tax havens. How much of these profits is the product of tax-avoiding accounting tricks is impossible to gauge. 


\section{TABLE 2}

Growth of Tax Haven Activity By Controlled Foreign Corporations of U.S. Multinationals 1968-1982

\begin{tabular}{|c|c|c|c|c|}
\hline \multirow[b]{2}{*}{ Industry of $\mathrm{CFCs}$} & \multirow[b]{2}{*}{ Year } & \multicolumn{3}{|c|}{ Earnings before tax of CFCs } \\
\hline & & $\begin{array}{l}\text { In tax } \\
\text { havens }\end{array}$ & $\begin{array}{c}\text { In all } \\
\text { countries }\end{array}$ & $\begin{array}{c}\text { In tax } \\
\text { havens } \\
(\%)\end{array}$ \\
\hline \multirow[t]{4}{*}{ All industries } & 1968 & $\$ 855$ & $\$ 7,744$ & 11.0 \\
\hline & 1972 & 1,972 & 15,356 & 12.8 \\
\hline & 1980 & 6,681 & 47,622 & 14.0 \\
\hline & 1982 & 7,405 & 36,696 & 20.2 \\
\hline \multirow[t]{3}{*}{ Finance, insurance, and real estate } & 1968 & 109 & 358 & 30.4 \\
\hline & 1972 & 422 & 1,190 & 35.5 \\
\hline & 1980 & 2,048 & 4,822 & 42.5 \\
\hline \multirow[t]{3}{*}{ Wholesale trade } & 1968 & 285 & 1,323 & 21.5 \\
\hline & 1972 & 731 & 2,141 & 34.1 \\
\hline & 1980 & 2,220 & 9,890 & 22.4 \\
\hline \multirow[t]{3}{*}{ Services } & 1968 & 34 & 117 & 19.2 \\
\hline & 1972 & 113 & 589 & 19.2 \\
\hline & 1980 & 365 & 1,841 & 19.8 \\
\hline \multirow[t]{3}{*}{ Other industries } & 1968 & 427 & 5,886 & 7.3 \\
\hline & 1972 & 706 & 1,436 & 6.2 \\
\hline & 1980 & 2,048 & 31,069 & 6.6 \\
\hline
\end{tabular}

Note: Dollar amounts are millions of current dollars. The following constitute the tax havens: the Bahamas, the Netherlands Antilles, Bermuda, Panama, Hong Kong, Liberia, Luxembourg, and Switzerland.

Source: States (1986-1987). Detailed industry earnings are not available by country for 1982.

estate industries, which have proclivities for tax haven locations. Indeed, the rising importance of these industries may in part be due to their ability to locate in low-tax countries.

The casual evidence from tax havens is consistent with the view that foreign tax systems influence the investment decisions of U.S. multinationals, and that this influence is growing. For those interested in American tax policy, the next question is to what extent the U.S. tax code affects the overseas investment decisions of our multinationals. In order to address that question, it is necessary to consider in detail some of the provisions of the code as they affect the taxation of foreign source income.

\section{THE TAX SYSTEM}

The tax treatment of income generated by overseas investments of U.S. multinational corporations is extremely complicated. This section contains 
a brief description of some of its primary features. To begin with, the United States uses a "residence" standard to tax its corporations, which means that U.S. corporations owe tax to the U.S. Treasury on all of their worldwide income, wherever earned. (The alternative system would be one of "territorial" taxation, under which the U.S. would tax only that corporate income actually earned in the United States and would not tax at all the offshore earnings of U.S. corporations. A number of European countries, including France and the Netherlands, use territorial-type tax systems.)

Thus, when U.S. multinationals earn profits in other countries, they owe U.S. taxes on these profits. In addition, U.S. multinationals are typically required to pay income and other taxes to the foreign countries in which they operate. Being subject to the tax authorities of not only their home country (the United States) but also their host countries (e.g., West Germany), ordinary treatment of the profits earned abroad by U.S. multinationals would subject them to double taxation. In order to prevent the same profits from being taxed twice, the U.S. tax system permits firms to receive a credit for income taxes paid to other governments. Under the credit system, U.S. multinationals first pay their foreign taxes and then calculate the taxes they would owe to the U.S. government based on their (pretax) worldwide income just as if all of their income were earned domestically in the United States. The income taxes paid to foreign governments are then credited toward payment of U.S. taxes, so that taxes otherwise owed the U.S. Treasury are reduced dollar for dollar by taxes paid to other governments. The practical operation of this credit can be anything but straightforward, however.

To take a simple example, suppose that a U.S. manufacturing firm has a branch in a foreign country that imposes a 20 percent tax on corporate profits. Assume the effective tax rate on U.S. corporations to be 34 percent. Upon earning $\$ 100$ through the foreign branch, the firm will owe $\$ 20$ to the foreign government and $\$ 14(\$ 100 \times 0.34-\$ 20)$ to the U.S. government. This calculation assumes the absence of a number of important real-world complications (discussed later).

United States corporations investing overseas generally can choose from among several forms of legal organization for these investments, an option that complicates tax analysis, since this choice may have dramatic tax consequences. The primary decision facing a U.S. multinational is whether to organize its foreign operation as a branch or as a controlled foreign corporation (CFC). ${ }^{3}$ Branch operations are considered by U.S. law to be

${ }^{3}$ United States multinationals can also organize their foreign affiliates with less than 50 percent U.S. ownership, thereby not qualifying as CFCs, but since there are reasons not to do 
integral components of the domestic U.S. corporation, so branch profits, losses, deductions, taxes paid, and other financial activities are all treated as if performed by the U.S. corporation. Not so with CFCs, which are legally separate entities, incorporated in host countries (e.g., West Germany), and are more than 50 percent owned by U.S. shareholders, each of which has at least $10 \%$ of the stock. ${ }^{4}$ Host countries often impose somewhat different tax and legal requirements on CFCs than they do on branch operations of U.S. multinationals. But the U.S. tax system treats CFCs very differently than it does foreign branches of U.S. companies.

The most important tax distinction between foreign branches and CFCs is that the United States taxes profits of the CFCs of U.S. multinationals only when CFCs send profits back to their U.S. parent companies. Legally, CFCs are entirely separate entities from the U.S. parent companies that own them, and it is only the U.S. parents that, strictly speaking, have tax obligations to the U.S. government. A U.S. parent is considered to earn income on its CFC investment only when that income is returned to the U.S. (with some exceptions). Thus, if a 100 percent American-owned CFC operates in Japan and runs up large profits there but does not pay out any dividends to the American corporation that owns its stock, then no U.S. tax liability is generated that year. Of course, U.S. taxes on those profits may have to be paid at some point in the future, if and when the profits are ultimately repatriated to the U.S. parent corporation.

When U.S. parent companies receive dividends from their CFCs, they calculate the U.S. taxes they owe based on the income they receive plus the foreign taxes credited to this income. ${ }^{5}$ The tax credit system is designed to treat repatriated CFC income in the same way that an equal amount of branch income would be treated. One legal complication is that when a foreign government taxes branch income, it is the U.S. corporation that

so and they typically use CFCs, the analysis in this paper assumes all nonbranch overseas operations of U.S. multinationals to be CFCs.

4 One question that naturally arises is, what are the consequences of less than 50 percent U.S. ownership of a foreign corporation? If an individual corporation owns less than 10 percent of foreign corporation, then it is not entitled to use the foreign tax credit when it receives taxable dividends in the United States. On the other hand, the Subpart F restrictions apply only to corporations that qualify as CFCs. Of course, there are a number of nontax reasons why a corporation might want more than 50 percent control of a foreign subsidiary. And the foreign corporation would presumably be less inclined to follow financial policies aimed at minimizing U.S. taxes of its shareholders if American firms own less than half the shares. In practice, in 1985 more than 75 percent of the U.S. share of earnings and assets of foreign corporation were located in majority-owned foreign affiliates, which includes foreign branches and a subset of all CFCs (see Brereton (1987)).

5 The 85 percent exclusion rule, which provides that U.S. corporations are taxed on only 15 percent of the dividends they receive on their corporate stock holdings, does not apply to dividends received from foreign corporations. 
officially pays the tax, whereas income tax paid by a CFC to a foreign government is, strictly speaking, paid by the CFC, not the U.S. corporation that owns the CFC. To handle this situation, the law provides that when the U.S. parent calculates the U.S. taxes it owes on dividends received from a CFC, the taxes paid to the foreign government by the CFC on this income are "deemed paid" by the U.S. parent and thereby can be added to the foreign tax credit the U.S. parent gets for foreign taxes paid on branch income.

When a U.S. parent corporation receives dividends from a CFC, the U.S. parent must determine the appropriate foreign tax credit (FTC) allowable on this income. Foreign tax credits have several sources, the most important being foreign withholding taxes and foreign income taxes. Many countries impose withholding taxes on CFC dividends remitted to U.S. parents, and U.S. corporations are allowed to credit these taxes toward their U.S. tax payments. ${ }^{6}$ It is trickier to calculate the allowable tax credit for the income taxes paid by the CFC. The basic method is to calculate the fraction of the current year's after-tax CFC income represented by the dividend, and multiply that fraction by the foreign taxes paid by the CFC to arrive at the foreign taxes the U.S. parent can credit toward its U.S. taxes. Table 3 illustrates this procedure for a simple example.

In this example, a U.S. parent corporation is assumed to own 75 percent of a foreign corporation that in the current year earns $\$ 5,000$ in profits. The foreign income tax rate is assumed to be 20 percent, "so the CFC pays foreign income tax of $\$ 1,000$ and has $\$ 4,000$ in after-tax profits. Assume the foreign corporation to pay out 60 percent of its after-tax profits as dividends, and that the foreign government imposes a 10 percent withholding tax on dividends sent to foreign shareholders. Since the American parent is entitled to 75 percent of the dividends paid out, it gets $\$ 1,800$ minus the 10 percent withholding tax, or $\$ 1,620$.

In calculating its U.S. tax liability, the U.S. parent is allowed to take a tax credit for the $\$ 180$ withholding tax paid on its dividend, plus a fraction of the $\$ 1,000$ paid this year by the CFC in income taxes. The fraction is determined by the ratio of the parent's pre-withholding-tax dividend $(\$ 1,800)$ to the CFC's after-tax income $(\$ 4,000)$, in this case $45 \%$. Thus, the U.S. parent gets a tax credit of $\$ 450$ for "deemed paid" income taxes plus $\$ 180$ for withholding taxes. But the U.S. parent is also required to "gross up" the dividend it receives from the CFC by the amount of the foreign

6 Strictly speaking, though they never actually see the money, the U.S. parent corporations pay these withholding taxes out of the dividends they would have received from their CFCs. Foreign governments require the CFCs to be withholding agents for these payments. As a result, the U.S. parents get full tax credits for the withholding taxes, and the foreign governments can lean on CFCs located in their countries to ensure that taxes are paid. 
TABLE 3

Illustrative Computation-U.S. Tax Liability from Repatriated CFC Profits

(1) Pretax earnings of CFC

(2) Foreign income tax at 20 percent

(3) Net earnings and profits: (1) - (2)

(4) Dividend paid to all shareholders: $60 \%$ of (3), by assumption

(5) Dividend paid to U.S. parent company: $75 \%$ of (4), by assumption

(6) Foreign withholding tax at $10 \%: 10 \%$ of (5)

(7) Net dividend received in U.S.: (5) - (6)

Foreign creditable taxes:

Direct credit for withholding tax

$\$ 5,000$

1,000

4,000

2,400

Deemed paid credit for subsidiary's income tax: $[(5) /(3)] \times(2)$

(8) Total creditable taxes

Includable as U.S. income:

Dividend received

Foreign deemed paid tax

(9) Total grossed-up foreign dividend

(10) U.S. tax due: $34 \%$ of $(9)$

(11) Foreign tax credit

(12) Net payment due U.S. government: (10) - (11)

Note: This table presents the end-of-year tax calculation for a U.S. parent company that owns 75 percent of a foreign corporation. The foreign income tax rate is assumed to be 20 percent, the foreign government imposes a 10 percent withholding tax on dividends paid to U.S. shareholders, and the foreign corporation pays out 60 percent of its after-tax earnings as dividends.

taxes deemed paid, so the U.S. tax liability is based on $\$ 2,250$ of foreign income. At a U.S. tax rate of 34 percent, the U.S. parent owes $\$ 765$ in U.S. taxes, but it can subtract $\$ 630$ in FTCs from this amount to yield a net payment due the U.S. government of $\$ 135$.

\subsection{Some Complications}

Although the FTC can be a strong palliative for the burden of foreign taxes, there are limits to the credit's applicability. For example, the FTC can be claimed only for income taxes; other types of taxes paid (or deemed paid) to foreign governments can generally be deducted like other business expenses but are not eligible for the credit. The distinction between foreign income taxes and other types of foreign taxes is, for this reason, important, but the distinction is sometimes murky. The law is designed to prevent U.S. multinationals from obtaining a U.S. tax credit for paying user fees disguised as foreign income taxes, but in practice it seems that the law disallows FTCs whenever the foreign taxes do not resemble U.S. corporate 
income taxes. ${ }^{7}$ On the other hand, withholding taxes on dividend remittances generally qualify as creditable income taxes, since they are attributed to be "in lieu of" income taxes that foreigners would have paid to their own governments had they been the shareholders.

In addition, there is an overall limit to the FTC: the law stipulates that a firm cannot apply more FTCs toward its U.S. tax liability than the total of its foreign source income times the average U.S. tax rate it pays. The FTC limitation is designed to enforce the restriction that FTCs cannot be used to offset taxes due on domestic U.S. income. That part of foreign taxes paid at a rate higher than the U.S. rate cannot be used as a tax credit in the current year. Since 1976, the U.S. government has required U.S. multinationals to average their worldwide foreign income and foreign taxes for purposes of calculating taxes and credits. This requirement limits the ability of U.S. firms to reduce their taxable income through foreign losses, but it allows firms to get credits for taxes paid in high-tax foreign countries by averaging with operations in low-tax countries. The slight nonlinearity of the U.S. corporate tax rate also affects the FTC limit, since the limit is based on average rather than marginal rates. Under the pre-TRA the U.S. corporate tax rate started at 15 percent and became 46 percent only once a corporation had income of $\$ 100,000$; furthermore, capital gains were taxed at 28 percent. Hence, a corporation that had much of its income in capital gains or that had low profits (or better yet, losses) would have an average tax rate below 46 percent and could credit only those foreign taxes that did not exceed this rate.

The structure of the FTC mechanism means that tax timing issues loom large for some U.S. multinationals, particularly those with substantial variations in foreign and domestic income. If a U.S. multinational cannot use all of its FTCs currently, it is permitted to carry them back up to two years or forward up to five years to reduce U.S. tax obligations on eligible foreign source income. Indeed, there is a significant inventory of unused FTCs that U.S. corporations carry forward each year. ${ }^{8}$

Another complication arises when CFCs pay out dividends exceeding their current year's income. In that event, the excess of current dividends over current income is attributed to previous years' undistributed incomes in reverse order, last year first. Firms are required, in other words, to keep

\footnotetext{
7 For example, certain foreign oil income taxes based on "posted price" rather than market revenues were disqualified as income taxes. McDaniel and Ault (1981) contains a discussion of this issue.

${ }^{8}$ For example, U.S. corporations carried accumulated FTCs of $\$ 17.5$ billion forward into 1982 while acquiring an additional $\$ 20.7$ billion credit that year. Only $\$ 18.9$ billion of those FTCs could be used in 1982, the bulk of the difference presumably eligible to be carried forward into future years. (See Barlow (1986) for 1982 data.)
} 
inventories of each year's income and dividends, reducing the inventories in last-in-first-out fashion as future dividends exceed future earnings. Given this accounting system, it is in the interest of U.S. multinationals that do not bump up against the FTC limit to receive dividends selectively from those of their CFCs having higher-than-average foreign tax years. Indeed, CFCs may reduce their overall tax burdens by taking actions that raise their average foreign tax burdens but at the same time increase their variability so that dividends can be paid in high-tax years. Industry sources suggest that firms make widespread use of this so-called "rhythm method" of paying dividends. The TRA limited (but did not eliminate) the ability of U.S. corporations to profit from year-to-year fluctuations in their CFCs' average foreign tax rates by providing that all post-1986 CFC earnings and foreign taxes be pooled to construct a multiple-year average foreign tax rate for purposes of calculating the indirect FTC.

Confident in the ability of U.S. corporations to exploit opportunities for tax avoidance, the U.S. Congress has written into the law a number of provisions that trigger tax obligations of U.S. parent companies for certain actions taken by their CFCs. The most important such provisions are the Subpart F rules, which were adopted in 1962. These rules attempt to discourage U.S. parents of CFCs from indefinitely delaying the repatriation of CFC income if minimizing U.S. taxes were the goal behind their no-dividend strategy.

The Subpart F rules provide that certain types of CFC expenditures or investments will be treated as if they were dividend payments to the U.S. parent, and hence will increase the U.S. tax obligation of the parent company. The most important category of these financial activities is passive investments. Thus, the profits of a U.S. multinational's French CFC are not taxable by the U.S. if reinvested in the French business, but the same profits if invested by the nonbank CFC in French bonds earn interest that is taxable in the United States as earned.

The Subpart F rules generally prevent nonfinancial CFCs from making financial investments in lieu of returning dividends to the United States. Besides passive investment income, Subpart $F$ requires $C F C$ investments in U.S. property and insurance of U.S. risks to be taxable as if the money were repatriated to the U.S. parent. Various earnings by CFCs in countries outside their host country trigger Subpart F tax liabilities, as do foreign illegal payments and income earned in countries that engage in certain illegal boycotts. Once the U.S. parent incurs a tax liability through Subpart $\mathrm{F}$, however, the Subpart $\mathrm{F}$ income can be repatriated to the United States without any further U.S. tax consequences.

The taxation of foreign source income raises issues that are not present or are less important to domestic business taxation. For example, the alloca- 
tion of income between countries can have very large tax consequences for U.S. multinationals. It is generally in the interest of multinationals to earn their income in low-tax jurisdictions. (Although, once earned, multinationals have incentives to attribute income to high-tax sources for FTC purposes.) Thus it might be tempting for U.S. multinationals to sell intermediate products to their foreign affiliates located in tax havens, at bargain prices, and to locate the head office and as many companywide fixed expenditures as possible in high-tax countries. But U.S. law generally requires firms to use market prices (or the equivalent) for intracompany transfers and to allocate fixed costs according to formulas based on criteria such as sales and assets. The law also restricts even the tax location of some assets; for example, income earned by Americans in outer space or in Antarctica is taxed as though earned on the ground in the United States. ${ }^{9}$

Other features of the tax law applying to foreign source income include much less generous investment incentives than those given to domestic capital until the recent tax reform. Foreign investments are not eligible for the investment tax credit and must be depreciated for tax purposes over long lifetimes. Special rules apply to foreign oil and gas income, and there are special recapture provisions that recoup in subsequent years tax losses that are usually associated with those industries. More generally, the TRA requires various baskets of foreign earning sources to keep separate accounts in hopes of preventing high foreign tax income, such as that derived from petroleum, from pooling tax credits with low foreign tax income from other sources. Other significant changes included in the tax reform include the introduction of functional currencies for foreign affiliates. Before passage of the TRA, the law was unclear over the appropriate way to treat for tax purposes changes in the value of foreign affiliates resulting from exchange rate movements. Under current law, each foreign affiliate chooses (usually) one functional currency and earns taxable income only for transactions in that currency.

\subsection{Implications for Investment Behavior}

The most striking features of U.S. taxation of multinational income are the provisions for credit and deferral. From a static and purely self-interested perspective, it may be hard to understand why the U.S. government permits a tax credit for foreign taxes paid. Taking the tax systems of foreign governments as given, foreign taxes paid by U.S. companies are costs of doing business and nothing more. As such, one might expect the U.S. government to permit a U.S. tax deduction for foreign taxes paid; but a credit goes beyond that. The FTC mitigates the double taxation of U.S. 
multinationals on their foreign earnings but does so by allowing foreign governments to extract tax revenues from U.S. companies without fear of excessively discouraging U.S. investment within their borders, since the cost is borne largely by the U.S. Treasury. In fact, even a tax deduction for foreign taxes paid might represent too generous a policy, since if American capital as a whole has market power overseas the U.S. government could create rents by taxing multinational investments (relative to allowing a deduction), restricting the quantity of American investments and raising their returns. But neither of these alternatives - a tax deduction for foreign taxes paid or only a partial deduction (or tax)—may make sense if other countries are thereby encouraged to adopt similar policies in taxing the U.S. investments of their own multinationals. All countries can be worse off in a worldwide regime of heavy double taxation of multinational income. The FTC is probably best understood as a measure designed to preserve an international political equilibrium of limited multinational taxes.

The deferral of U.S. taxes on unrepatriated CFC income further encourages U.S. investment abroad. By reinvesting their foreign CFC earnings in active investments in foreign host countries, where tax rates are lower than the U.S. tax rate, U.S. multinationals can effectively earn interest abroad on what would have been taxes due to the U.S. government. Even though U.S. taxes are ultimately due on all foreign earnings, firms are generally better off by delaying their U.S. tax payments. Hence deferral has two consequences: it may encourage initial equity investments by U.S. parents in their foreign CFCs, since the returns are lightly taxed, and CFCs have particularly strong incentives to invest out of retained earnings, since those funds are subject to U.S. tax if not reinvested.

The deferral of U.S. taxes is widely thought to have substantial effects on CFC investment behavior. Horst (1977) argues that deferral lowers (in the case of a U.S. tax rate that is higher than foreign taxes) the effective tax rate on CFC investments to a weighted average of U.S. and foreign tax rates, with weights determined by the CFC's (fixed) dividend payout ratio. Hartman (1985) argues that deferral is even more powerful than that: he claims that the reinvestment decisions of mature CFCs will be completely unaffected by U.S. tax considerations. Newlon (1987) arrives at the same conclusion, using a model that includes the full range of financial options available to the multinational firm. In the Hartman and Newlon models the U.S. tax system can affect only the initial equity investments of U.S. multinationals overseas. Once firms have sufficient retained earnings abroad, they finance their own investments out of these earnings as if the U.S. tax rate on this income were zero. Assuming foreign tax rates to be lower than U.S. rates, CFCs of U.S. multinationals will therefore reinvest 
their earnings to a greater degree than would those companies in the United States. Hartman (1981), Frisch and Hartman (1983), and Boskin and Gale (1987) tested whether domestic tax variables affect foreign investment by U.S. multinationals out of retained earnings and found no significant effect. But these regressions encounter difficulties acknowledged by the authors, and in section 5 explores channels through which U.S. taxes affect CFC reinvestment decisions that the earlier studies do not incorporate.

United States companies are not the only entities whose behavior is likely to be affected by U.S. provisions for taxing the foreign income of U.S. multinationals. Foreign governments may respond, or threaten to respond, in a retaliatory fashion to aggressive U.S. tax increases. The worldwide averaging provision of the U.S. tax code may encourage some high-tax countries to raise their taxes on U.S. multinationals in order to free ride off other, low-tax, countries where U.S. multinationals generate income. In addition, foreign governments have incentives to design their tax systems to show a high rate of income tax that is eligible for the U.S. FTC. As Gersovitz (1987) argues, the optimal strategy for a host country often is to tax multinationals at a high rate while offering other direct or indirect investment subsidies, thereby encouraging investment and allowing U.S. firms to claim hefty FTCs. Baldwin (1986) reports that indirect subsidies for multinational investment are quite common, including U.S. government subsidies for foreign investment projects in the United States.

\section{HOW BIG ARE U.S. TAXES?}

Much of the preceding discussion was predicated on the assumption that the U.S. tax rate on foreign source income exceeds foreign tax rates. If the U.S. tax rate exactly equalled foreign tax rates, then the U.S. tax system would raise no revenue from foreign sources and have no effect on the overseas behavior of U.S. multinationals. Unfortunately, it is not easy to construct summary statistics on the difference between U.S. and foreign tax rates, since applicable statutory tax rates as well as depreciation and other provisions vary widely from one country to another.

Table 4 presents some evidence on the relative historic magnitudes of average foreign and U.S. tax rates on foreign source income of U.S. multinationals. Of course, these tax rates represent tax collections as a fraction of realized taxable income and so do not reflect many of the tax incentives that affect investor decisions by encouraging lightly taxed activities and discouraging business activities taxed at full rates. In addition, these figures do not incorporate unreported foreign income of U.S. firms or the incentives generated by the tax system to earn foreign income in ways that are easily hidden from U.S. tax authorities. Still, Table 4 


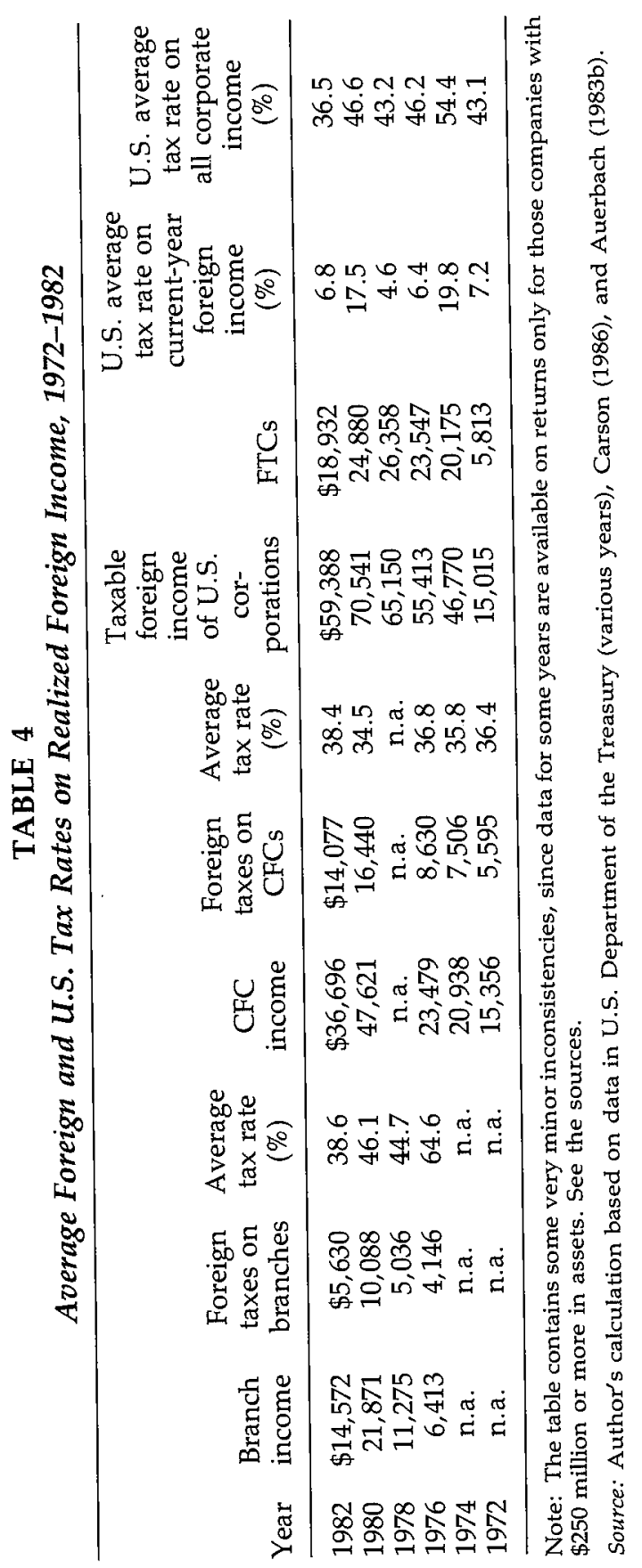


presents a picture of foreign tax rates that are slightly lower than the average U.S. corporate tax rate. As a result, U.S. taxes have generally been due on foreign income received by U.S. corporations, though at a fairly low average rate.

What does the evidence in Table 4 suggest about the likely effect of U.S. taxes on overseas investments by U.S. multinationals? Since tax collections on foreign source income are positive, it is tempting to infer that firms must pay positive U.S. taxes on repatriated profits, a tax obligation they can defer by continued reinvestment abroad. One difficulty in drawing that conclusion is that, once again, these tax rates reflect average rather than marginal incentives for a firm's foreign investment. In addition, these numbers represent averages across firms and countries. It may be that the CFCs of individual firms located in particular countries face very high or very low effective tax rates on their marginal investments. The TRA, with the reduction in the U.S. corporate tax rate from 46 to 34 percent, is also likely to change the relative sizes of U.S. and foreign tax rates. United States taxes on multinational investment can be expected to diminish in importance; Grubert and Mutti (1987) report Treasury estimates that 70 percent of U.S. manufacturing companies will have excess FTCs.

Even if the U.S. Treasury collected no corporate revenue at all from foreign source income, it would be a mistake to conclude that U.S. taxes have no effect on foreign investment behavior of U.S. multinationals. As discussed in the previous section, the U.S. tax system may induce U.S. multinationals to reduce their U.S. tax liabilities by adjusting the rate at which they pay out dividends, by modifying their use of tax deductions in foreign countries, and by changing the location of overseas investments, all of which have real effects on the after-tax returns available from investments in other countries. Consider the simple case in which a U.S. corporation wants to repatriate some of the income earned by one of its CFCs located in a foreign country with very high taxes. Taken alone, the dividend payment would generate no additional U.S. tax liability, since the associated FTCs exceed the average U.S. taxes that would have to be paid. But by generating foreign tax in excess of the credit limit, this action encourages the same U.S. parent company to repatriate income from CFCs located in low-tax countries, since worldwide averaging permits the U.S. parent to apply the high foreign taxes to the rest of its repatriated income that year and bring the average down to the limit. This technique thereby removes some of the repatriation disincentive for investments in low-tax countries and may contribute to the popularity of tax havens as investment locations. One implication of widespread use of this technique would be average realized foreign tax rates on repatriated income near the U.S. 
statutory corporate rate, and low average U.S. tax rates on repatriated income, both of which one observes.

None of this should be taken to minimize the importance of interfirm heterogeneity in applicable marginal tax rates on foreign investments and repatriations to the United States. Some firms carry forward unused FTCs each year, whereas other firms pay substantial taxes on their foreign source income. Although a similar tale can be told of the unused tax credits and deductions of unprofitable domestic U.S. firms going to waste while other U.S. firms face full tax rates (see Auerbach and Poterba (1987)), the rules that apply to foreign source income make it particularly difficult for unused FTCs to find their way into the books of companies that can exploit them. Without tax data on individual firms one cannot know precisely their incentives, but it is still possible to make some general observations about the average tax incentives U.S. firms face. The next question is whether observed behavior is consistent with those incentives.

\section{FINANCIAL BEHAVIOR AND TAX INCENTIVES}

Because profits earned abroad by the CFCs of U.S. multinationals are not subject to U.S. taxation until received by their U.S. parents, it is to the advantage of these CFCs to delay paying dividends as long as feasible, thereby reducing the present value of the associated U.S. tax obligations. In fact, one well might wonder why CFCs remit dividends to U.S. parents at all, given the tax cost of doing so. A similar question arises in studies of the financial behavior of domestic U.S. corporations, since individuals who own corporate stock are typically taxed much more heavily on the dividends they receive than on their capital gains. Hence, shareholders should prefer their companies to reinvest all their profits, in government bonds if necessary, rather than pay dividends. By reinvesting the profits, the companies would raise the value of their shares and shareholders could take their returns in the form of lower-taxed share appreciation rather than dividends. Or less subtly, corporations can and do return profits to stockholders in lightly taxed form through share repurchases, as Shoven (1987) documents.

In fact, domestic U.S. corporations pay out about one-quarter to onethird of their profits to their shareholders each year in dividends, as indicated in the first column of Table 5 . By contrast, column 3 of Table 5 reveals CFCs to payout a significantly higher fraction-almost half-of their annual profits out in dividends each year. The accounting rules underlying these ratios are somewhat arbitrary (see Poterba (1987) for a discussion), but they reveal what appears to be a significant difference in the financial behavior of domestic corporations and their CFCs. In order to 


\section{TABLE 5}

CFC Dividend Payouts and U.S. Corporate Dividend Payouts

\begin{tabular}{ccccc}
\hline & $\begin{array}{c}\text { Dividend } \\
\text { payout ratio, } \\
\text { all U.S. } \\
\text { corporations } \%\end{array}$ & $\begin{array}{c}\text { Implicit } \\
\text { shareholder } \\
\text { tax rate on } \\
\text { U.S. } \\
\text { dividends } \%\end{array}$ & $\begin{array}{c}\text { Dividend } \\
\text { payout } \\
\text { ratio, CFCs } \%\end{array}$ & $\begin{array}{c}\text { Average U.S. tax } \\
\text { rate on foreign } \\
\text { earnings \% }\end{array}$ \\
\hline 1982 & 30.6 & 24.8 & 64.8 & 6.8 \\
1980 & 23.9 & 30.5 & 45.3 & 17.5 \\
1978 & 22.3 & 28.7 & n.a. & 4.6 \\
1976 & 24.2 & 28.6 & 44.2 & 6.4 \\
1974 & 28.7 & 28.2 & 51.8 & 19.8 \\
1972 & 26.8 & 28.6 & 52.9 & 7.2 \\
\hline
\end{tabular}

Note: First and second columns adapted form Poterba (1987).

Sources: Author's calculation based on data in U.S. Department of the Treasury (various) and States (1980-1987). Some CFC data refer only to CFCs whose U.S. parent corporations have assets of at least $\$ 250$ million.

understand the source of this difference, it helps to explore the reasons why firms pay dividends in the first place. Financial policy is particularly important to the investment decisions of CFCs, since the Subpart F and other rules imply that the tradeoff between dividends and investments in plant and equipment is even stronger for them than it is for domestic firms.

Observers of U.S. corporate financial policy have proposed several explanations for the presence of significant dividend payments despite associated tax costs. The most important of these explanations include the use of dividend payouts by a firm's managers to signal profitability, the willingness of tax-exempt and certain other shareholders to receive dividends rather than accrue capital gains, and the possibility that a reinvested dollar may not raise firm value by a full dollar. The first explanation relies on incompleteness of information flows between firms and their shareholders. By paying dividends, firms reassure their shareholders and the market generally that operations continue to be profitable. By contrast, a reduction in dividends signals pessimistic news about current and future profitability and is likely to depress firm value. Since publicly traded American firms are required to release their financial information to the public, dividends under the signaling interpretation must be conveying information beyond that which firms routinely make available through annual reports, $10-\mathrm{K}$ filings, and the like. ${ }^{10}$

The second explanation for dividend payouts by firms to shareholders is the possibility that tax-exempt shareholders hold the stock of high-payout

10 Gordon and Malkiel (1981) explore the consequences of this view of dividend behavior. 
firms, making those payouts costless from a tax point of view. Then if shareholders would have to incur transactions costs in selling stock, those shareholders would prefer to receive their returns in the form of dividends rather than capital gains. In addition, corporate shareholders can exclude from their taxable income 85 percent of the dividends they receive from domestic corporations, so they generally prefer to receive dividends rather than capital gains. ${ }^{11}$

The third explanation of dividend behavior is the so-called "trapped money" model: once a corporation earns money, it must choose either to pay the money out as a dividend or to reinvest the money. Since corporations are observed to pay some dividends, this model implies that a marginal dollar reinvested in the firm produces the same after-tax addition to shareholder value as would the same dollar paid as a dividend. Assuming tax rates on capital gains to be lower than dividend taxes, it must be the case that $\$ 1$ of marginal investment financed by reinvested earnings is sufficiently unproductive that it raises firm value by less than $\$ 1 .{ }^{12}$

Although none of these three models of firm financial policy appear to explain every feature of domestic dividend behavior, it is worth considering how they can be applied to the dividend remittance decisions of CFCs of U.S. multinationals. At first blush, it seems unlikely that information and signaling problems would arise between CFCs and their U.S. multinational parents, since it is all one company and the parent could in principle demand to see detailed financial records, fire foreign managers, and exert control in other ways. Furthermore, the U.S. parent as (in many cases) the only shareholder need not be troubled by temporary changes in share value. But at the same time, one cannot rule out the same kind of agency problems that arise between ordinary corporate shareholders and their firm's managers. Domestic managers of U.S. multinationals inevitably have less information about the financial well-being of foreign affiliates than do their foreign managers, and continued high-dividend payouts provide convincing evidence of the high quality of overseas operations. But this effect seems unlikely to explain payout ratios that exceed even those of domestic corporations.

The second explanation for domestic dividends, the presence of low-tax shareholder clienteles, says little about dividend remittances to heavily taxed multinationals. But the third explanation, that corporate money is

11 Auerbach (1983a) finds some support in data on stock price movements for the hypothesis that low-tax shareholders tend to own stock in firms with high dividend-payout ratios, but even in his estimates these individuals prefer capital gains to dividends.

12 See Auerbach (1979), Bradford (1981), and King (1977) for the development of this model. Poterba and Summers (1985) do not find support for this theory in their recent examination of U.K. data. 
"trapped" within inescapable tax barriers, appears to be very much to the point of multinational financial planning. What can a CFC do with its earnings when there appear to be no profitable foreign investment opportunities? The Subpart F rules prevent passive and other types of internationally invested income from going unrecognized by the U.S. tax system, so dividends to parent companies entail no extra tax cost to the multinational. Of course, these dividends then represent income that the U.S. parent corporation must either reinvest or pay out as dividends to its shareholders. The profits of CFCs are thus subject to taxation three times: they are taxed by foreign governments when earned, by the U.S. government when repatriated, and by the U.S. government when distributed ultimately to stockholders. But CFCs cannot avoid indefinitely the last two layers of taxation, and so should be expected to remit dividends in response to declining foreign uses of capital. ${ }^{13}$

Controlled foreign corporations need not pay dividends mechanically, however: the model implies that payout ratios should be sensitive to the associated U.S. tax obligations, and the evidence suggests that they are. Recall from Table 5 that CFC payout ratios are higher than overall U.S. corporate ratios, which is consistent with the lower average U.S. tax rate on CFC dividends than on domestic corporate dividends paid to individual shareholders. In addition, CFC payout ratios vary over time and between CFCs as the U.S. taxes due on CFC dividends vary. Table 6 illustrates the response of payouts to taxes with aggregate CFC data for 1980 and 1982. All other things equal, CFCs facing the highest foreign taxes have incentives to pay dividends at the highest rates, since these dividends may be untaxed by the U.S. government and, indeed, through worldwide averaging these dividends might reduce U.S. taxes due on foreign source income that was lightly taxed by foreign governments. The last column of Table 6 suggests that payout ratios do generally rise with foreign tax rates. This evidence is consistent with other findings that the dividend policies of multinational firms respond to foreign and U.S. tax regimes.

13 One implication of the model is that CFCs that pay dividends should never simultaneously receive equity transfers from their parents. Jun (1987) presents new evidence that more than a quarter of foreign affiliates pay dividends and receive transfers in the same year. But these data do not conclusively reject the theory, since the sample includes branches as well as CFCs, the transfers include debt as well as equity, and the timing of financial operations within the year may be important here. Furthermore, under the current system of worldwide averaging, U.S. parents desire immediate repatriation of profits earned by their CFCs located in countries with taxes higher than U.S. rates, replenishing them if necessary with equity transfers in the same year. The presence of CFCs in high-tax countries may account for Jun's findings.

14 See, for example, Kopits (1972) and Mutti (1981). 


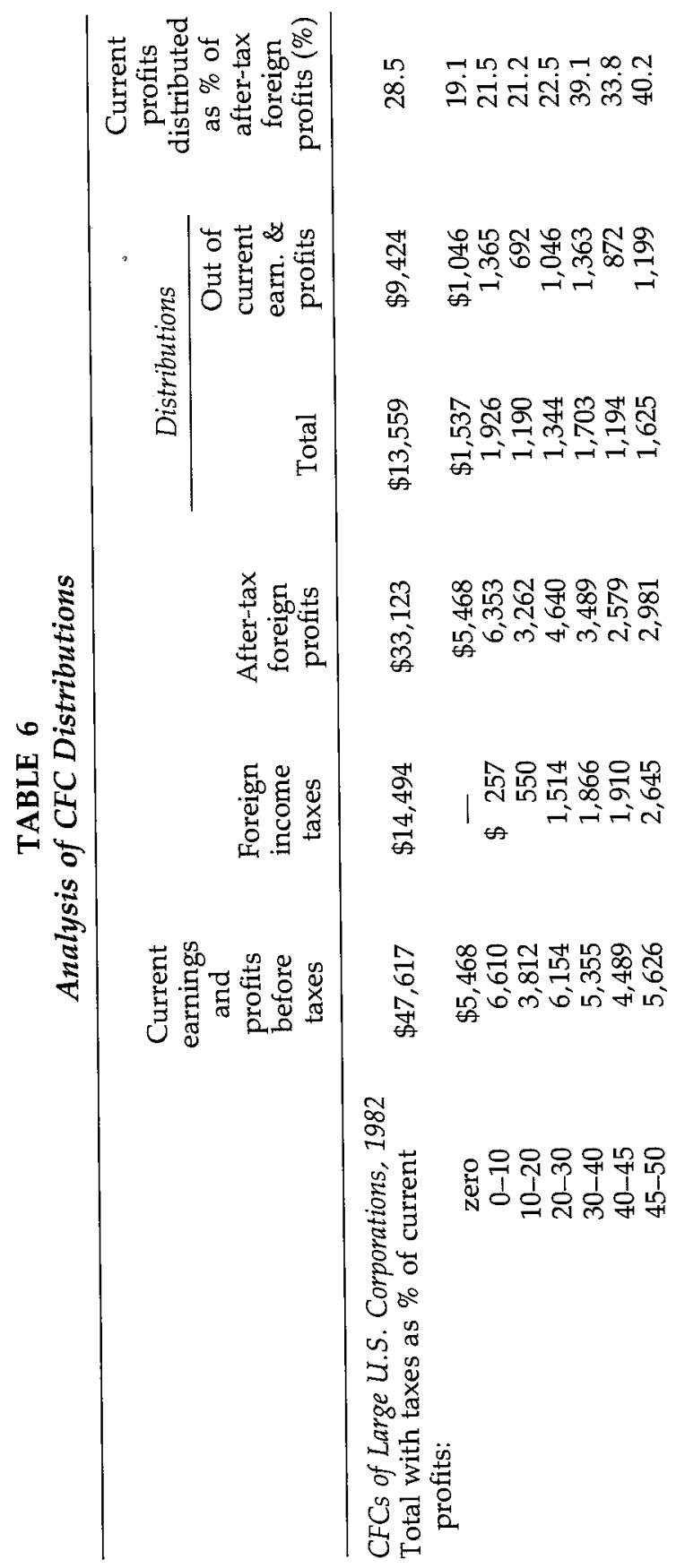




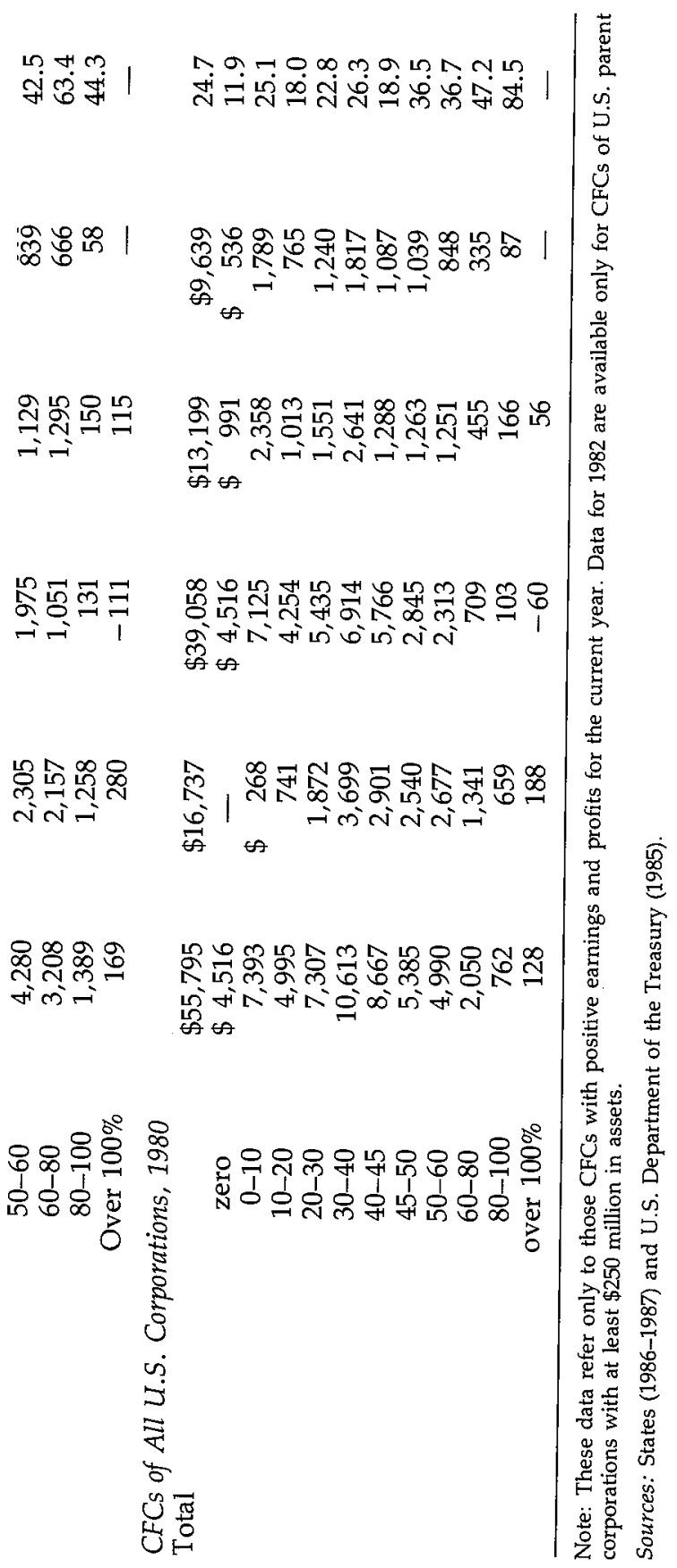




\section{EFFECTIVE TAX RATES AND U.S. INVESTMENT}

\section{ABROAD}

The tax incentive for U.S. firms to invest abroad is a subject of major policy interest. As earlier discussion indicates, any individual firm's tax incentives depend on its available tax credit carryforwards, earnings, and tax history against which to carry back deductions and credits, fungibility of currentyear dividend repatriations from CFCs in high- and low-tax countries, borrowing opportunities, and a host of other factors. In addition, when new investment opportunities arise, they can be exploited in a number of different forms.

United States multinationals can choose from among three primary methods of investing in foreign countries: branch investments, CFC investments financed out of new transfers of debt or equity from the parent corporation, and CFC investments financed out of retained earnings. Since it is not clear with which of these methods marginal multinational investments take place, it is necessary to analyze the investment tax incentives for all three.

Foreign branch investments are seemingly the most straightforward, since repatriation-timing issues do not arise because branches are taxed currently in the U.S. on all their earnings and profits. As mentioned earlier, the U.S. tax treatment of foreign branches differs from the tax treatment of analogous domestic U.S. investment in that branches must pay taxes to foreign governments at rates possibly higher than U.S. tax rates, and branches are not entitled to some domestic investment incentives such as the investment tax credit and short asset lifetimes for tax depreciation purposes. One big tax advantage that branch organization may offer a U.S. multinational is that foreign branch losses reduce domestic taxable profits dollar for dollar. Since U.S. multinationals are not permitted to use CFC losses to reduce domestic or foreign taxable income, it may be in the interest of firms expecting loss years to organize their foreign operations as branches. It is widely argued that the tax losses associated with oil and natural gas exploration and development motivated U.S. oil companies to form foreign branches rather than CFCs for their overseas operations. Naturally, legal, regulatory, and political considerations also may affect the decision to form a foreign branch rather than a CFC.

New investments financed out of the retained earnings of existing CFCs have the tax advantage of avoiding direct U.S. taxation of either the principal or subsequent profits until profits are repatriated. It is this feature that motivated Hartman (1985) to argue that only the foreign country's tax system affects the marginal incentive for CFCs to invest out of retained 
earnings. Although Hartman's conclusion is correct for the stylized model he constructs, it is not accurate to conclude that U.S. CFCs with retained earnings face no marginal investment incentives from the U.S. tax code. In particular, the difference between the U.S. definition of foreign earnings and profits and the foreign definition of taxable income generally produces a tax burden on U.S. multinational investment in excess of the foreign effective tax rate.

No two foreign tax systems look exactly alike; however, they typically share the feature that they encourage corporate investment through incentives such as very rapid tax write-off of depreciation charges for new investments. Canada, for example, has very generous investment incentives in the manufacturing industries. When U.S. multinationals make investments through their CFCs, they must calculate their earnings and profits based on "U.S. accounting principles," which provide, among other things, for tax depreciation of investment expenses at slow rates over long depreciable lifetimes. As a result, a new U.S. investment in Canada generates a present value of U.S.-definition earnings and profits that is higher than the present value of Canadian-defined taxable income.

This difference in U.S. and foreign definitions of income, along with the method by which tax credits are computed, means that the U.S. corporate tax rate and U.S. rules for depreciation of foreign property generally combine to discourage even the marginal investments of U.S.-owned CFCs that use retained earnings. The reason the U.S. tax system has this effect is that a new CFC investment will in general change the calculated value of a firm's average foreign tax rate that is used in the tax credit computation. As a result, even though the profits from a new CFC investment may not be themselves subject to U.S. taxation, the accounting rules work in such a way that this investment reduces the FTC the U.S. parent firm is eligible to take on profits from other foreign investments made by the same CFC, as long as the tax rate on marginal investments is lower than the average tax rate paid that year. A complete calculation of the true tax incentives for CFC investments should include this effect along with the standard tax incentive provided by foreign law.

By defining foreign income in this way, the U.S. tax law discourages U.S. overseas investments in countries with significantly different income definitions. It is difficult to establish in practice exactly how much of a difference these accounting rules make in the level of reported earnings, but Table 7 provides some suggestion that the difference may be quite substantial. As the table reports, the measured profit margins on sales by CFCs of U.S. multinationals are consistently significantly higher than profit margins of all U.S. corporations. To be sure, these higher profit margins undoubtedly also reflect the different natures of domestic and multinational 


\section{TABLE 7}

Profit Margins of CFCs and All U.S. Corporations Compared

\begin{tabular}{|c|c|c|c|c|}
\hline & \multicolumn{3}{|c|}{ Controlled Foreign Corporations } & \multirow{2}{*}{$\begin{array}{c}\text { Profit } \\
\text { margins of } \\
\text { all U.S. } \\
\text { corporations } \\
(\%)\end{array}$} \\
\hline & $\begin{array}{l}\text { Business } \\
\text { receipts }\end{array}$ & $\begin{array}{c}\text { Current } \\
\text { earnings and } \\
\text { profits before } \\
\text { taxes }\end{array}$ & $\begin{array}{c}\text { Profit } \\
\text { margin (\%) }\end{array}$ & \\
\hline 1982 & $\$ 647.9$ & $\$ 36.7$ & 5.66 & 3.51 \\
\hline 1980 & 699.0 & 47.6 & 6.81 & 4.17 \\
\hline 1976 & 342.8 & 23.5 & 6.85 & 5.50 \\
\hline 1974 & 281.3 & 20.9 & 7.44 & 5.11 \\
\hline 1972 & 172.4 & 15.4 & 8.91 & 4.82 \\
\hline
\end{tabular}

Note: Dollar amounts are billions of current dollars.

Source: U.S. Department of the Treasury (1985) and Simenauer (1986).

businesses, the efforts of U.S. multinationals to transfer at reduced prices their high-profit assets to CFCs and away from U.S. taxing jurisdiction, and other business activities of multinationals. Furthermore, it is not obvious how one is to interpret evidence on profit margins, since firms try to maximize profits rather than their margins. Given the limited financial data available, however, the size of CFC profit margins as measured by U.S. accounting principles suggests that use of these principles may substantially overstate CFC profits (relative to the U.S. definition) and, by extension, reduce U.S. multinational tax credits and discourage CFC reinvestment.

Table 8 presents calculations of adjusted effective tax rates for investments made out of retained earnings by CFCs of U.S. multinationals in selected industrial countries in $1982 .{ }^{15}$ Column 4 contains estimates of effective tax rates for reinvested CFC earnings without correcting for the U.S. definition of foreign income. These effective tax rates are basically the same as those faced by foreign firms reinvesting in their own countries. Column 5 presents corrected effective tax rates for U.S. CFCs. With the exception of West Germany, the corrected effective tax rates are higher than the uncorrected rates, significantly so in Canada and the United Kingdom where the governments offer very fast depreciation write-offs on new capital as investment incentives. By contrast, West Germany insists on slow capital cost recovery so the U.S. tax system encourages investment there relative to the incentives faced by West German firms.

These effective tax rate calculations are based on the same assumptions

15 Among these countries, the United Kingdom has significantly changed its taxation of corporate profits since 1982 . 


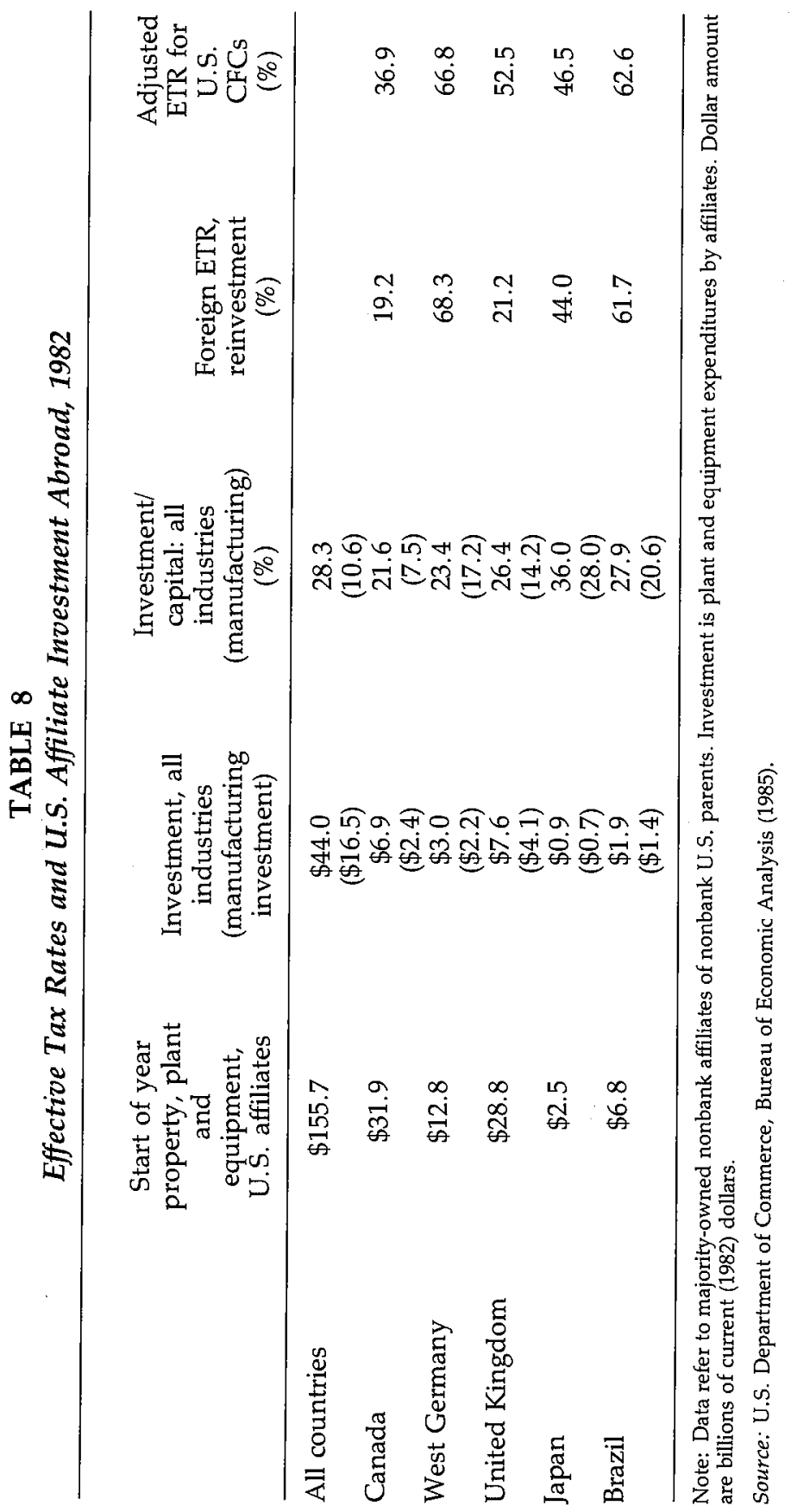


embodied in Auerbach's (1983b) estimates of effective tax rates on U.S. domestic investment: firms choose accounting policies to minimize taxes, and investors require 4 percent real after-tax returns. For these estimates, inflation expectations are assumed to be static, firms invest in asset combinations similar to aggregate U.S. corporate investment, and these assets depreciate at the same rates as those assumed by Auerbach for the United States. In addition, the average realized U.S. tax rate on foreign income is assumed to be 10 percent, and the average dividend payout ratio on the CFC's other investments is assumed to be 50 percent. Though stylized, these assumptions correspond to observed average behavior of U.S. CFCs. ${ }^{16}$ Foreign tax parameters are based on data from Price Waterhouse (various), where when necessary values were chosen which correspond most closely to the foreign tax treatment of new manufacturing investment. Given the special tax provisions affecting other important industries, it probably makes the most sense to interpret these effective tax rates as applying primarily to manufacturing firms. As such, they can be compared to effective tax rates of around 25 percent, which Auerbach (1983b) estimates for domestic U.S. manufacturing investment in 1982. The adjusted effective tax rates on foreign investments are uniformly higher.

It is instructive to associate the investment/capital ratios in column 3 of Table 8 with the corresponding effective tax rates. In a first pass there appears to be little correlation: Japan and Brazil exhibit the highest investment ratios without having the lowest effective tax rates. But Japan's adjusted effective tax rate is the second lowest, and the table may illustrate the importance of adjusting foreign effective tax rates to account for the effects of U.S. taxes. Without doing so, Canada and the United Kingdom show by far the lowest effective tax rates, and their 1982 investment ratios suggest that such investment incentives may be absent. In fact, the wedge between domestic effective tax rates and the effective tax rate on foreign investment may partly account for lagging foreign investment behavior.

Naturally, it is a mistake to infer too much from one year's worth of investment and tax data. This is particularly true when different types of investments face different tax rates, and Table 8 presents data only on the tax rates on CFC profits reinvested in manufacturing (though other tax rates should move more or less in tandem). Unfortunately, one has few options in this case. Table 8 presents data for 1982 because it is the only recent year for which the U.S. Commerce Department has detailed survey

16 Of course, these calculations illustrate that marginal investment incentives are sensitive to a firm's average foreign tax rate, and these tax rates differ widely. The reported numbers are based on overall average foreign tax rates, but these may not be the average foreign tax rates of marginal investors. 
data on U.S. multinationals. The multinational investment and tax picture is likely to look very different with the U.S. passage of the TRA and the excess FTCs it generates. Furthermore, U.S. domestic tax incentives were largely removed by the Act, and it remains to be seen whether U.S. multinationals are thereby encouraged to move more of their operations and investments abroad.

\section{CONCLUSION}

Taxes have historically played an important role in influencing multinational investment decisions. Although the consequences of the incentives offered by tax havens are plainly visible, the effect of U.S. taxes on the foreign investments of American multinationals may be no less real. Contrary to the claims of earlier authors, the U.S. tax system appears to have had a significant influence on marginal after-tax returns available to investors in foreign assets.

There are several channels for this influence of the U.S. tax system. The U.S. tax code defines income differently than do foreign governments for their own tax purposes, which has generally worked to discourage U.S. multinational investments in countries with strong investment incentives. The potential tax obligation due the U.S. government on repatriation of foreign earnings has influenced multinational financial policy, encouraging firms to pay dividends from high-tax sources and retain earnings (thereby investing) in low-tax countries. The generally heavy taxation of U.S. individual shareholders on dividends encourages U.S. corporations to retain earnings to a greater degree than they would otherwise, and foreign affiliates of U.S. multinationals should be subject to the same incentive. Finally, though not explored here, U.S. taxes may affect the profitability of overseas investments by U.S. multinationals through influencing the rate of accumulation of complementary capital in the United States.

The TRA appears to change many of these incentives. By reducing the U.S. tax rate, the Act all but relieves most U.S. multinationals of U.S. tax obligations on their foreign income. But time will tell what the long-run effects of tax reform will be on multinational investment. Possibly much of the effect will depend on the reaction of foreign governments to U.S. tax changes, a process that is difficult to predict and still appears to be evolving.

\section{REFERENCES}

Auerbach, Alan J. 1979. Wealth maximization and the cost of capital. Quarterly Journal of Economics 93 (August 1979): 433-46.

. 1983a. Shareholder tax rates and firm attributes. Journal of Public Economics 21 (July 1983): 107-27. 
1983b. Corporate taxation in the United States. Brookings Papers on Economic Activity 2: 451-505.

Auerbach, Alan J., and James M. Poterba. 1987. Tax loss carryforwards and corporate tax incentives. In The effects of taxation on capital accumulation ed. M. Feldstein. Chicago: University of Chicago Press.

Baldwin, Carliss Y. 1986. The capital factor: Competing for capital in a global environment. In Competition in global industries ed. Michael E. Porter, Boston: Harvard Business School Press.

Barlow, Mary. 1986. Foreign tax credit by industry, 1982. Internal Revenue Service, S.O.I. Bulletin 5, 9-29.

Boskin, Michael J., and William G. Gale. 1987. New results on the effect of tax policy on the international location of investment. In The effects of taxation on capital accumulation ed. M. Feldstein. Chicago: University of Chicago Press.

Bradford, David F. 1981. The incidence and allocation effects of a tax on corporate distributions. Journal of Public Economics 15 (April 1981): 1-22.

Brereton, Barbara F. 1987. U.S. multinational companies: Operations in 1985. Survey of Current Business 67:6.

Carson, Chris R. 1986. Corporate foreign tax credit, 1982: A geographic focus. Internal Revenue Service, S.O.I. Bulletin 6, 21-48.

Frisch, Daniel J., and David G. Hartman. 1983. Taxation and the location of U.S. investment abroad. NBER Working Paper no. 1241.

Gersovitz, Mark. 1987. The effects of domestic taxes on foreign private investment. In The theory of taxation for developing countries. eds. David M. G. Newbery and Nicholas H. Stern. New York: Oxford University Press.

Gordon, Roger H., and Burton G. Malkiel. 1981. Corporation finance. In How taxes affect economic behavior. eds. Henry J. Aaron and Joseph A. Pechman. Washington, D.C.: Brookings.

Grubert, Harry, and John Mutti. 1987. The impact of the Tax Reform Act of 1986 on trade and capital flows. In Treasury Compendium of Tax Policy Research. Washington, D.C.: U.S. Department of the Treasury.

Hartman, David G. 1981. Domestic tax policy and foreign investment: Some evidence. NBER Working Paper no. 784.

1985. Tax policy and foreign direct investment. Journal of Public Economics 26: $107-21$.

Horst, Thomas. 1977. American taxation of multinational firms. American Economic Review 67: 376-89.

Jun, Joosung. 1987. Taxation, international investment and financing sources. Harvard University, mimeo.

King, Mervyn A. 1977. Public policy and the corporation. London: Chapman and Hall.

Kopits, George F. 1972. Dividend remittance behavior within the multinational firm: A cross-country analysis. Review of Economics and Statistics 54: 339-42.

McDaniel, Paul R., and Hugh J. Ault. 1981. Introduction to United States international taxation. Deventer, The Netherlands: Kluwer.

Newlon, Timothy Scott. 1987. Tax policy and the multinational firm's financial policy and investment decisions, unpublished Ph.D. dissertation, Princeton University.

Mutti, John. 1981. Tax incentives and reparation decisions of U.S. multinational corporations. National Tax Journal 34: 241-48. 
Poterba, James M. 1987. Tax policy and corporate saving. Brookings Papers on Economic Activity 2.

Poterba, James M., and Lawrence H. Summers. 1985. The economic effects of dividend taxation. In Recent advances in corporate finances. eds. Edward I. Altman and Marti G. Subrahmanyam. Homewood, Ill: Irwin.

Price Waterhouse. Corporate taxes—a worldwide summary. New York: Price Waterhouse. Various annual editions and individual country guides.

Shoven, John B. 1987. The tax consequences of share repurchases and other non-dividend cash payments to equity owners. Tax Policy and the Economy 1: 29-54.

Simenauer, Ronald. 1986. Controlled foreign corporations, 1982: An industry focus. Internal Revenue Service, S.O.I. Bulletin 6, 63-86.

States, Williams. 1986-1987. Controlled foreign corporations, 1982: A geographic focus. Internal Revenue Service, S.O.I. Bulletin 6, 49-80.

U.S. Department of Commerce, Bureau of Economic Analysis 1985. U.S. direct investment abroad: 1982 benchmark survey data. Washington, D.C.: Government Printing Office.

U.S. Department of the Treasury, Internal Revenue Service 1979. U.S. corporations and their controlled foreign corporations, 1968 and 1972. Washington, D.C.: Government Printing Office.

- 1980. U.S. corporations and their controlled foreign corporations, 1974-1978. Washington, D.C.: Government Printing Office.

- 1981, Foreign tax credit claimed on corporation income tax returns, 1974. Washington, D.C.: Government Printing Office.

. 1982, Foreign income and taxes reported on U.S. income tax returns, 1976-1979. Washington, D.C.: Government Printing Office. 1985, Compendium of studies of international income and taxes, 1979-1983. Washington, D.C.: Government Printing Office. 
